\title{
全芳香族ポリアミドに対する放射線照射効果
}

\author{
日本原子力研究所大阪研究所 梶加名子 ・ 岡田紀夫
}

\section{RADIATION EFFECTS ON WHOLLY AROMATIC POLYAMIDES}

\author{
By Kanako Kaji and Toshio Okada \\ (Osaka Laboratory for Radiation Chemistry, \\ Japan Atomic Energy Research Institute, \\ Neyagawa, Osaka 572, Japan)
}

Radiation effects on poly ( $m$-phenylene isophthalamide) ( $m$-PIA) and poly ( $\rho$-phenylene terephthalamide) ( $p$-PTA) fibers have been studied by use of $r$-rays and electron beams.

Deterioration in the mechanical properties was not observed for $m$-PIA or $p$-PTA fiber even after irradiation of $1000 \mathrm{Mrad}$ in vacuo. The presence of air favored the degradation of wholly aromatic polyamides as in case of aliphatic polyamides, although a much larger irradiation dose was needed for the former than for the latter to give the same degradation in mechanical properties by irradiation. The irradiation up to $1000 \mathrm{Mrad}$ with electron beams in air revealed that $p$-PTA is more stable against irradiation than $m$-PIA.

Viscometric studies were carried out on the irradiated fibers. Only a small change in viscosities of $p$-PTA was found even after irradiation both in the presence and absence of air up to a large dose, whereas in $m$-PIA, gel was formed after $\gamma$-ray irradiation of about $200 \mathrm{Mrad}$ in vacuo and viscosity decreased to $40 \%$ of the original value after $r$-ray irradiation of about $500 \mathrm{Mrad}$ in air.

No or a very small change in TGA curves for $m$-PIA and $p$-PTA was observed even after the irradiation of $1000 \mathrm{Mrad}$, showing that the irradiation at room temperature had no appreciable effect on the thermal degradation of these polymers.

(Received January 27, 1978)

\section{1. 緒言}

全芳香族ポリアミド紻維はすぐれた耐熱性，難然性を もち、種々のタイプの全芳香族ポリアミド繊維が開発さ れ、いわゆる high performance fiberとして奏用化さ れつつある ${ }^{1,2)}$

放射線を固体高分子に照射すると，分子間に架橋が起 こり，分子鎖に切断反応が起とって固体高分子の物理的 性質が変化することはよく知られている゙、中。

脂肪族ポリアミドにと線を照射すると架橋することは 古くから知られている。また，架橋上同時に主鎖の切断

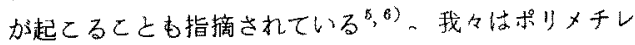
ン基の長さの異なる一連の脂肪族ポリアミげ対する 線照射効果を研究し，その結果の一部はすでに報告し だ。しかしながらポリメチレン銷を芳香舆に置き換え
た構造を有する全芳香族ポリアミドに対しては，放射線 照射効果の采統的な研筧はほとえどされていない。

芳香族ポリアミドは紫外線に対しては，脂肪族ポリア ミド同様不安定であり，分子鎖の切断が容易に起こるこ とが報告されている8，文。しかしながらべンゼン核が放 射線照射に対して保護効果があるこよは，ポリスチレン あるいはスチレンを含む共重合体 ${ }^{10}$ ，11)，あるいはベンゼ ン環を導入したセルロース ${ }^{12)}$.ポリビニルアルコール に対する照射効果の研究より明らかにされた。

この研究の目的は全芳香族ポリアミトが放射線照射に 対してどのような挙動をするかを明らかにすることにあ る。それによって耐放射線性材料に関する基碟的知識を 得ることも出来る。

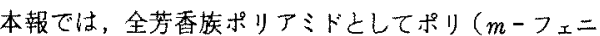
レンイソフタルアミド $(m-\mathrm{PIA})$ 拈よびホリ $(p-フ ェ$ 
ニレンテレフタルアミド) ( $p$ - PTA)をとり上げ，r線 あるいは加速器よりの電子線を照射し，機械的性質，溶 液粘度の測定，ゲル分率の測定などを行い，照射効果を 検討した結果について報告する。

\section{2. 実験方法}

\section{1 試 料}

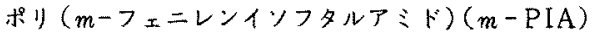
は帝人社のコーネックス* (Conex $\left.{ }^{\circledR}\right)$, ポリ $(p-フ ェ=$ レンテレフタルアミド) (p-PTA)はDu Pont 社のケ プラ* (Kevlar $\left.{ }^{\circledR}\right)$ を用いた。コーネックスは2デニー ルのステープルヤーン.ケブラは1.5デニールのフィラ メントである。

\section{2 照 射}

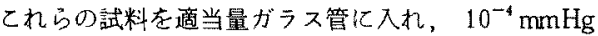
以上の真空中, あるいは空気中で、Co $60 r$ 線 $\left(2.8 \times 10^{5}\right.$ $\mathrm{rad} / \mathrm{h})$ を $22^{\circ} \mathrm{C}$ て照射した。V.d.G.䨮子線 $\left(3.5 \times 10^{\circ}\right.$ $\mathrm{rad} / \mathrm{sec}$ ) は空気中で断続照射し，照射湿度か $50^{\circ} \mathrm{C}$ 以 上には上らないよう留意した。なお吸収楾量は $r$ 線の場 合，鉄線量計により水の吸収係数を用いて計算した線量 率より求めた。電子線の場合は, フィルム線量計（セル ローストリアセテートフィルム)を用いた。

\section{3 棋械的性需の測定}

インストロン試験器を用い， $23 \mathrm{C} ， 65 \%$ RH 強度お よび伸度を測定した。試料長は $10 \mathrm{~mm}$ ，引張速度は10 $\mathrm{mm} / \mathrm{min}$ である。

\section{4 溶液粘度の測定, ケル分率の測定}

95 硫酸を溶媒にし，濃度 $0.1 \mathrm{~g} / \mathrm{dl} ， 30^{\circ} \mathrm{C}$ に求ける罡 元粘度を測定した。

ゲル尔率の測定は，試料索 $95 \%$ 硫酸に $30^{\circ} \mathrm{C}$ で 3 日間 浸漬した後、不溶部分を洰别，水，アルコールで十分洗 浄し，減圧乾燥して重量を測定した。百分率で表したゲ は, $\frac{\text { 不溶部分の重量 }}{\text { 陚料の重量 }} \times 100$ で求められる。

\section{5 熱重量分析}

真空理工社製，Micro Differential Thermal Balance TGD- 3000 を用い, 空気 $の$ 存在下に昇温速度 5 $\mathrm{C} /$ 分，最高温度 $700 \mathrm{C}$ 条件で熱 重量分析 (TGA) 行った。

\section{3. 結果および考察}

图 1 に架気中てC 060 線を $200 \mathrm{Mrad}$ まで照射した 場合の $m$-PIA 々 $p$-PTAの照射量に上る強度保持率の 変化を示す。図には 2 デニールのナイロン6フィラメン *コーネックスは帝人，ケブラはユニチカおよじ東レよ り惠与された。

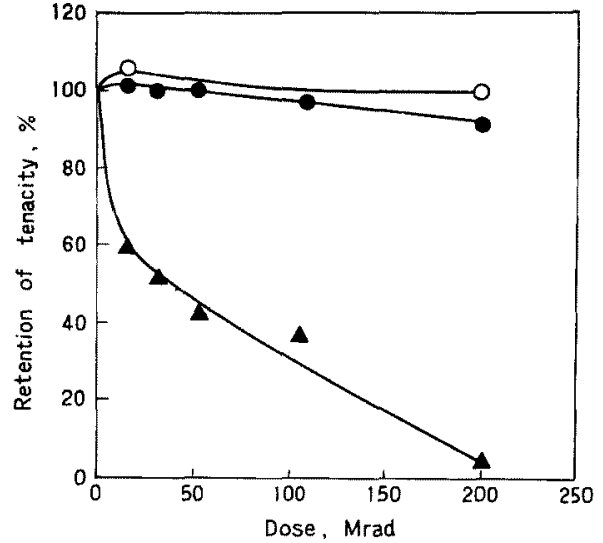

Fig. 1 Effect of irradiation on tenacity of polyamides irradiated with Co $60 r$-rays in air, (O) poly ( $\rho$-phenylene terephthalamide), (-) poly ( $m$-phenylene isophthalamide), ( $\triangle$ ) nylon 6.

卜を空気中で照射した場合の强度保持率の変化む同時に 示した。ナイロン6は真空中r線照射では架橋反心が優 先的に起こるが空気中炤射では $30 \mathrm{Mrad} の$ 照射で强度 は未照射の $1 / 2$ に低下し，200Mrad 照射すると强度 ははとんど0になる。しかしながら，m-PIA, $p$-PTA は空気中 $200 \mathrm{Mrad}$ の照射でも強度低下はほ之んどみら れない。このように，全芳香族ポリアミドである $p$-PTAは脂肪族ポリアミドであるナイロン6に比較し て著しく耐放射線性がありり,ベンゼン核による放射線保 護効果は明らかである。

次に $m$-PIAおよび $p$-PTAに対する放射線照射効果 を更に詳しく知る目的で，Co 60 r線を用いる真空下， 空気存在下o照射，V.d.G. 電子楾を用いる空気存在下 の照射を線量を更に大きくして行った。

表 1 に注 $m$-PIAの照射による強伸度の変化を示す。 $r$ 線真空中照射では，強度の低下はなくむしろやや增 大する傾向がみられる。伸度む余り変化がない。一方 線空気中照射の場合は，穆量が大きくなと強度，伸度 の低下がみられ，脂肪族ポリアミドの場合上同様，酸素 の存在が分子の崩㯰を促進していることがかかる。しか しながら，ナイロン6の場合，約 $10 \mathrm{Mrad} の$ 照射で強度 が原㵶維の75\%にあで落ちるのに反し， $m$-PIAの場合 は同様の強度低下を起とすのに約 $500 \mathrm{Mrad}$ の線量を要 していることがわかる。次にV.d.G. 電子線照射（空気 中) の場合は $r$ 線空気中照射の場合上り強伸度の低下は 小さい。乙れは $r$ 線に比較して電子線の線量率が約 4500 倍高いことにより，同じ線量を短時間照射で得るととが 
Table 1. Effect of irradiation on mechanical properties of poly ( $m$-phenylene isophthalamide)

\begin{tabular}{lrcccc}
\hline & $\begin{array}{c}\text { Dose } \\
(\text { Mrad })\end{array}$ & $\begin{array}{c}\text { Tenacity } i \text {. } \\
(\mathrm{g} / \mathrm{d})\end{array}$ & $\begin{array}{c}\text { Retention of } \\
\text { tenacity }(\%)\end{array}$ & $\begin{array}{c}\text { Elongation } \\
(\%)\end{array}$ & $\begin{array}{c}\text { Retention of } \\
\text { elongation (\%) }\end{array}$ \\
\hline & 0 & 4.9 & 100 & 31 & 100 \\
& 8 & 5.5 & 111 & 35 & 113 \\
Co 60 & 22 & 5.2 & 105 & 31 & 100 \\
$r$ - rays & 103 & 4.9 & 100 & 30 & 97 \\
(in vacuo) & 212 & 5.3 & 108 & 35 & 113 \\
& 487 & 4.9 & 100 & 29 & 94 \\
& 1000 & 5.7 & 116 & 29 & 94 \\
& 1430 & 5.4 & 110 & 31 & 100 \\
\hline & 8 & 4.9 & 100 & 30 & 97 \\
Co 60 & 16 & 5.0 & 102 & 30 & 97 \\
$\gamma$ - rays & 105 & 4.8 & 97 & 30 & 97 \\
(in air) & 200 & 4.5 & 91 & 24 & 80 \\
& 338 & 4.2 & 86 & 21 & 58 \\
\hline & 523 & 3.7 & 75 & 17 & 97 \\
V. d. G. & 15 & 5.1 & 104 & 30 & 101 \\
Electrons & 65 & 5.5 & 111 & 31 & 93 \\
(in air) & 103 & 4.8 & 97 & 28 & 58 \\
& 200 & 5.2 & 106 & 29 & 52 \\
\hline
\end{tabular}

Table 2 Effect of irradiation on mechanical properties of poly ( $p$-phenylene terephthalamide)

\begin{tabular}{lrcccc}
\hline & $\begin{array}{c}\text { Dose } \\
\text { (Mrad) }\end{array}$ & $\begin{array}{c}\text { Tenacity } \\
(\mathrm{g} / \mathrm{d})\end{array}$ & $\begin{array}{c}\text { Retention of } \\
\text { tenacity }(\%)\end{array}$ & $\begin{array}{c}\text { Elongation } \\
(\%)\end{array}$ & $\begin{array}{c}\text { Retention of } \\
\text { elongation (\%) }\end{array}$ \\
\hline Co 60 & 0 & 26.9 & 100 & 6.3 & 100 \\
$r$ - rays & 15 & 27.4 & 102 & 7.1 & 113 \\
(in vacuo) & 500 & 27.3 & 101 & 6.6 & 105 \\
& 1000 & 28.4 & 106 & 7.0 & 111 \\
\hline Co 60 & 15 & 28.6 & 106 & 6.8 & 108 \\
$r$ - rays & 500 & 24.7 & 92 & 6.5 & 103 \\
(in air) & 1000 & 21.5 & 80 & 5.5 & 87 \\
\hline V. d. G. & 15 & 29.2 & 109 & 6.9 & 110 \\
Electrons & 500 & 27.3 & 101 & 6.5 & 89 \\
(in air) & 1000 & 25.3 & 94 & 5.6 & 89 \\
\hline
\end{tabular}

出来、酸素の試料内人の拡散が少くなる結果上考元られ る。なお，実際の照射時間は $1000 \mathrm{Mrad}$ 照射に対して $r$ 線の場合は 7 8 ケ月，電子線の場合は約 5 時間であ った。

表 $2 k p-\mathrm{PTA}$ 照射による強伸度の変化を示す。 楾真空中照射の場合は $1000 \mathrm{Mrad} の 大$ 大線量照射におい てあ強伸度の低下はみられない。一方 $r$ 線空気中照射で は，強伸度が照射に上りやや低下する傾向比ある。との

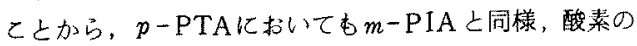
存在が分子の崩壊を促進していることがわかるが、 $m^{-}$
PIAが約 $500 \mathrm{Mrad}$ の空気中煦射で強度が $75 \%$ まで落 ちるのに比ふ， $p$-PTAの場合は, $1000 \mathrm{Mrad}$ 照射でも 强度保持率は $80 \%$ であり， $p$-PTAの方が $m$-PIAに比 してより放射楾汶対して安定であることが明らかである。 V.d.G. 電子線照射 (空気中) の場合は， $r$ 線空気中照 射比比酸素の影響加少く $1000 \mathrm{Mrad} の$ 照射に拉いて あ強伸度に大きな变化はない。

次汇照射による分子量の变化を知る目的で，分子量の 目安として還元粘度の変化を測定した。

$m$-PIA， $p$-PTA の照射による還元粘度の变化を末 

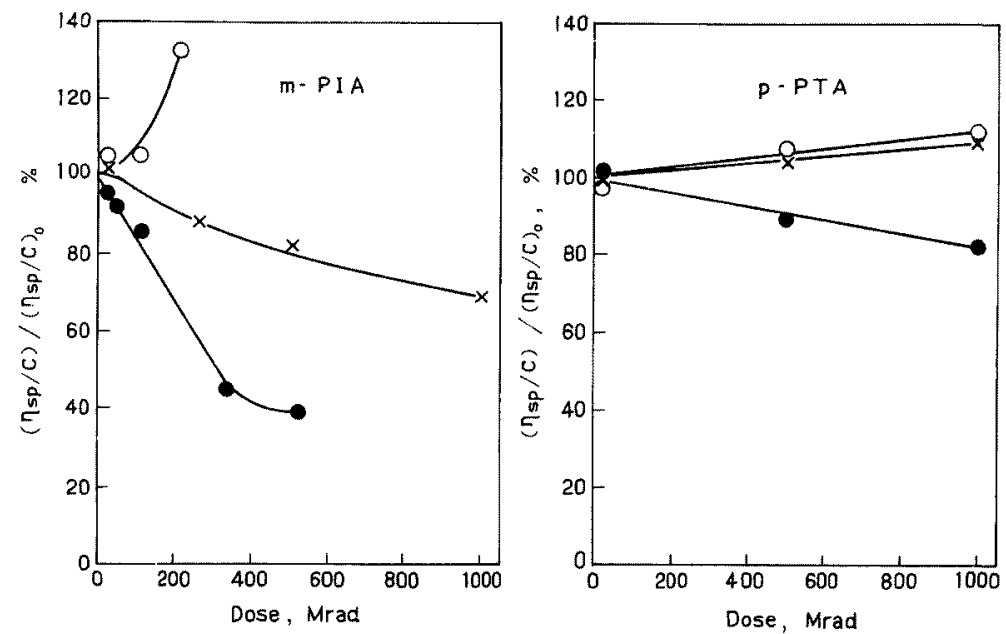

Fig. 2 Effect of irradiation on reduced viscosity of poly ( $m$-phenylene isophthalamide) and poly ( $p$-phenylene terephthalamide), (O) Co 60 $\gamma$-rays in vacuo, (•) Co $60 \gamma$-rays in air, $(x) \mathrm{VdG}$ electron beams in air.

照射の値を $100 \%$ として示したのが図 2 である。 PIAの場合， $r$ 線真空中照射では，強伸度の变化は 1000 Mradの照射に抬いても僅かであったが，粘度は照射量 の増大に伴いかなり大きくり，230 Mradの照射で溶媒 不溶のゲルが生成する。このことから全芳香族ポリアミド の場合も，脂肪族ポリアミド同様，真空中照射の場合は 架橋反応が優先して起こっているととがわかる。しかし ながら、ナイロン6や610などの脂肪族ポリアミドのゲ 儿化線量が約 $30 \mathrm{Mr}$ adであるのと此較すると，全芳香族 ポリアミドm-PIAのゲル化にば約 10 倍の線量を要し ており，放射線によって变化を受けにくいてとは明らか である。 量の増大と共に粘度の減少がみられ，約 $300 \mathrm{Mrad}$ で粘 度は末照射の半分になる。てれは機械的性兵の变化加ら 予想した通り，空気中照射では，主銷の切断反応が優先 的に起こっているととを示している。V.d.G. 電子線照 射 (空気中) の場合はやはり，主鎖切断反応が優先して いるが，照射眰の增大に伴う，粘度低下の度合いは $\gamma$ 線 の場合より小さい。これ住主鎖の切断反応が空気の存在 によって促進されること，線量率の高い電子線の場合，

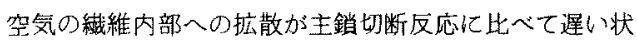
態になっていることを示している。

次に $m$-PIAの真空中 $r$ 線照射に求いては，照射量の 增大と共に溶液粘度が增大し，やがて溶媒不溶のゲル部 分が生成するととが加ったので，架橋の挙動を詳しく 検討するために，種々の線量において，ゲル分率の測定

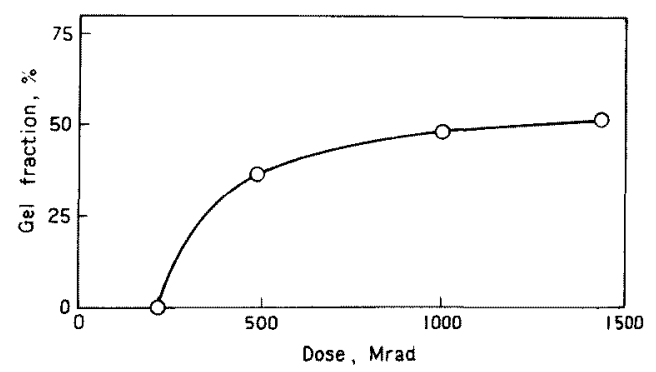

Fig. 3 Influence of the dose on the gel fraction of poly ( $m$-phenylene isophthalamide) irradiated with Co $60 r$-rays in vacuo.

を行った。図 3 にゲル分率－線舅曲線を示す。ゲル分率 一線量曲線から明らかなように，m-PIAを真空中で 線照射した場合，200Mrad 起えるとゲル部分が生じ $1000 \mathrm{Mrad}$ 照射でゲル分率は $50 \%$ になる。しかしそれ 以上楾量を大きくしてもゲル化は余り進まない。これは 真空中照射においても主銧切断反応がかなりの割合で起 とっているととを示している。

$p$-PTAの還元粘度は真空中 $r$ 線照射, 空気中 $r$ 線照 射 V.d.G.電子線照射 (空気中)，何れの場合も 1000

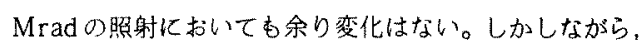
真空中 $r$ 線照射の場合はやや粘度が增大する傾向にあり， 一方，空気中 $r$ 線照射の場合はやや堿少する傾向がみら れ，同じ程度の変化を引起とすのに要する線量は $m$ - 
PIAより大きいが，やはり真空中照射では架橋反応が， 空気中照射では主鎖切断反応汃㵵先的に起こっているこ とがわかる。

機械的性質，溶液粘度の照射化上る変化上り， $m$-PIA より $p$-PTAが更に放射線に対して安定であるこ上がわ かったが，これは分子の一次構造の差だけではなく，結 晶化度の違いがより大きく効いているのではないか子考 えら机る。 $m$-PIAの結晶化度は約 $35 \%, p$-PTAの之

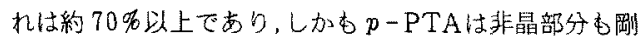
直な配向した状態にある構造が提案されている ${ }^{14)}$ 。

次に，真空中照射でゲル化の進んだ $m$-PIAに対し， 照射に上る架橋上主鎖切断のG 值を求めるために，次の 取报い老行った。

すなわち，照射量上ゲル分率の関係纪関してはCharlesly - Pinner の式がある。

$$
\begin{aligned}
& S+\sqrt{S}=\frac{0.48 \times 10^{6}}{M_{n_{0}} \cdot G(X)} \frac{1}{r}+\frac{G(S)}{2 G(X)} \\
& S \quad: \text { ゾル分率 } \\
& G(S): \text { 切断の } G \text { 值 } \\
& G(X): \text { 架橋の } G \text { 值 }
\end{aligned}
$$$$
M_{n_{0}} \text { ：原武料 (未照射試料) の数平均分子量 }
$$

ゲル分率上線量の関倸を(1) 式にあてはめ, $S+\sqrt{S}$ を $\frac{1}{r}$ に対してプロットすると图 4 が得られる。真空中 照射 $m$-PIAに関してこのプロットはほぼ直線汇乗り， ての直線の勾配打上び切片加ら $G(X)$ ならびに $G(S)$ 在

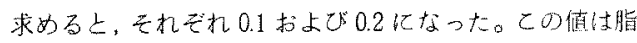
肪族柿リアミドに比皎して数分の1加ら1标小さい值で ある。

$p$ - PTAの真空中 $\gamma$ 線照射の場合は, $1000 \mathrm{Mrad} の 大$ 線量を照射して屯ゲル部分は生じないで, Charlesly 一Pinner ブロットを適用出来なかったが，原試料の分 子量を $m$-PIA上等しく，加切断反応は起こらない上 仮定すると架橋の $G$ 値は 0.01 以下になり，m-PIA上り 更に1桁小さい值になる。

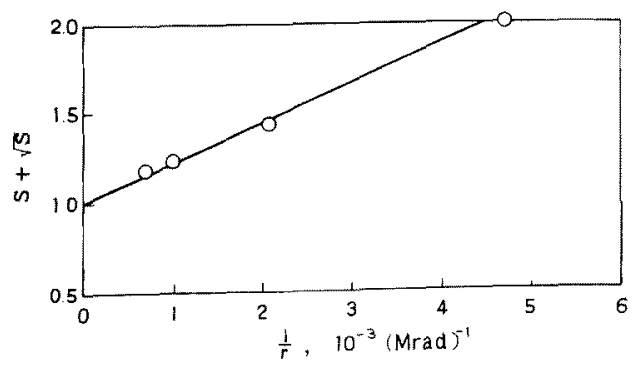

Fig. 4 Charlesby-Pinner plot of poly ( $m$-phenylene isophthalamide) irradiated with Co $60 \mathrm{r}$. rays in vacuo.
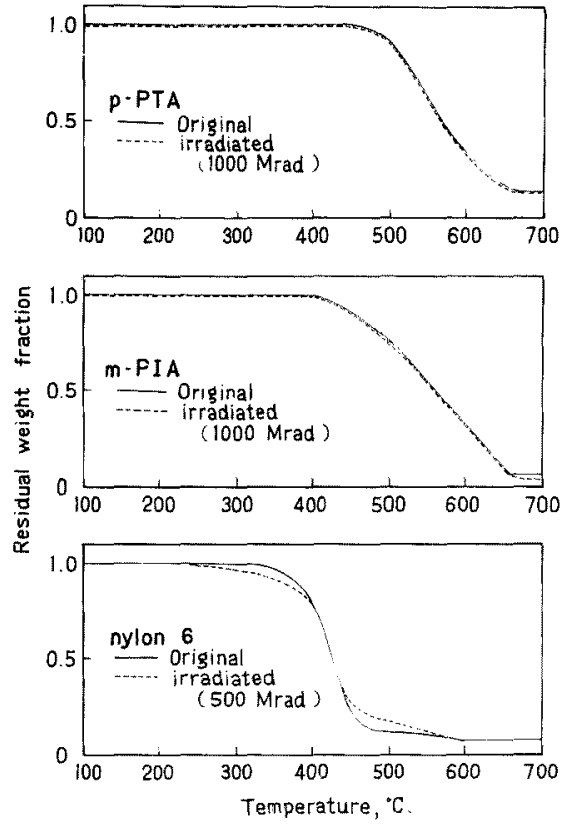

Fig. 5 Effect of irradiation on TGA curves of polyamides in air.

Electron beam irradiation in air.

次に全芳香族ポリアミドの揰熱性に対する照射の影響 を检討するために，熱重量分析老行った。 $m$-PIA, $p$ PTAならびに比較のために行ったナイロン6に刘する 空気中に扔けるTGAの測定の結果を図 5 に示す。奉線 は末照射の試料，点線は $m$-PIA，p-PTAに関しては

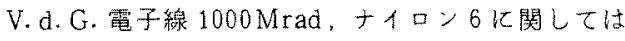
V.d. G. 電子線 $500 \mathrm{Mrad}$ 照射試料のTGA曲線である。

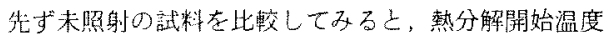
はナイロン60300年比へ， m-PIA $390^{\circ} \mathrm{C}, p-$ PTAは $440^{\circ}$ 己菖くなり，TGA曲線は高温側に移動し でり，脂肪族ポリアミドの耐熱性比して，全芳香族 ポリアミトツ酎熱性が大きいととを示している。これら の試料老照射した場合，ナイロン6は500 Mradの照射 厄、熱分解開始湿度が $250^{\circ} \mathrm{C}$ 红まで下, $250^{\circ} \mathrm{C}$ 加ら400 Cにかけて重量損失の增大がみられる。しかしながら， $m$-PIA， $p$-PTAの場合は1000Mrad 照射の後に あTGA曲線は全く変化甘ず，熱分解特性からみた耐熱 性は照射によりはとんど影響を受けていないととが明ら かとなった。

\section{4. 総括}

全努香族ポリアミド，ポリ（mーフェーレンイソフタル 
アミド)( $m$-PIA)およびポリ（p-フェーレンテレフタ ルアミド)(p-PTA)に対する放射線照射効果をCo 60 $r$ 線，およびV.d.G.電子線を用い検討した。 $m$-PIA， $p$-PTA共真空中照射に拈いては 1000 Mradの照射に斿いても強伸度の低下ははとんどなく， むしろやや増大する䫍向がみられる。空気中照射におい ては強伸度は照射によりやや减少し，酸素の存在が主銷 切断反応を促進していることがわかる。しかし，脂肪族 ポリアミドのナイロン 6 が $200 \mathrm{Mrad}$ の空気中 $r$ 線照射 で強度が原繊維の4\%に減少するのに反し，m-PIAの 強度保持率は $91 \%$-PTAのそれは $99 \%$ であり，全芳 香族ポリアミドが脂肪族ポリアミドに比較して著しく放 射線に対して安定であることが明らかになった。

溶液粘度の测定より，全芳香族ポリアミトに括いても 脂肪族ポリアミド同様，真㚙中照射においては架橋反応 が，空気中照射においては主銷切断反応が優先している ととが明らかになった。

熱分解特性加らみた酎熱性は1000 M rad 0 照射後も 損なわれていないてとがわかった。

付記：本研究の一部は昭和 52 年 6 月䋐維学会年次研 究発表会 (東京)において発表したものである。

本研究に際し, 御指導頂いた桜田一郎先生に感謝しま †。
女 献

1) W. B. Black and J. Preston, eds:; "HighModulus wholly Aromatic Fibers", Marcel Dekker Inc., N.Y., 1973.

2) Technical Report from Du Pont, 1974.

3) E. J. Lowton, A. M. Beuche and J. S. Balwit; Nature, 172, 76 (1953).

4) A. Charlesby; "Atomic Radiation and Polymers", Pergamon Press, London, 1959.

5) S. A. Pavlova, S. R. Rafikov and B. L. Tsetlin; DAN SSSR, 123, 127 (1958).

6) T.G. Majury and S.H. Pinner; J. Appl, Chem., 8,168 (1958).

7) K. Kaji, T. Okada and I. Sakurada; TAERI, 5027, 26 (1971).

8) G. Hargreaves and J.H. Bowen, Jr.; Text. Res. J., 43, 568 (1973).

9) M. I. Morton, Text. Res. J., 44, 332 (1974).

10) P. Alexander and A. Charlesby; Proc. Roy. Soc., A230, 136 (1955).

11) S. Okamura and Y. Oishi; Isotopes and Radiation, 2, 407 (1959).

12) J. C. Arthur, Jr. and T. Mares; J. Appl. Polymer Sci., 9, 2581 (1965).

13）幸寺加名子，木村藤子，桜田一郎；放高協年報， 8, $43(1966 \sim 1967)$.

14) 田所厷行; 擮学誌, 31, P-278(1975). 